\title{
SLIPS OF THE TONGUE IN INDONESIAN DAILY CONVERSATION: A PSYCHOLINGUISTIC VIEW
}

\author{
Merry Lapasau \\ Universitas Indraprasta PGRI Jakarta \\ Sulis Setiawati \\ Universitas Indraprasta PGRI Jakarta \\ Jalan Nangka no. 58 C Tanjung Barat, Jagakarsa, Jakarta Selatan \\ e-mail: mlapasau@gmail.com
}

\begin{abstract}
This research aims at analyzing speech errors, also known as slips of the tongue made by adult Indonesians as native speakers. Those errors were analyzed regarding types and background of the occurence with Meringer's theory of slips of the tongue as the framework of the research. This research is mainly qualitative with a descriptive approach within the psycholinguistics view. The results show that slips of the tongue occurred by adult Indonesian as native speakers were: 1. Exchange, 2. Anticipation, 3. Postposition, 4. Contamination, and 5. Substitution. Researchs about slips of the tongue can provide input to the language process which is very important for language teaching. Language teachers can interact better with students if the problems as the sources of the students' errors are identified. Above all, by comprehending various types of speech errors we can increase our understanding of the acquisition, production, and perception of our language thoroughly.
\end{abstract}

Key Words: speech error; slips of the tongue; psycholinguistics

Article History: Received: 16/09/2020; Revised: 11/10/2020; Accepted: 25/11/2020; Published: 31/12/2020

How to Cite (MLA $7^{\text {th }}$ ): Lapasau, Merry, and Sulis Setiawati. "Slips of The Tongue in Indonesian Daily Conversation: A Psycholinguistic View." Hortatori Jurnal Pendidikan Bahasa dan Sastra Indonesia 4.2 (2020): 127-132. Print/Online. Copyrights Holder: Merry Lapasau, Sulis Setiawati. First Publication: Hortatori Jurnal Pendidikan Bahasa dan Sastra Indonesia (2020).

\section{Pendahuluan}

Berbicara merupakan kegiatan tipikal biasa manusia yang mendampingi kegiatan kita setiap hari. Namun, penelitian psikolinguistik beberapa tahun terakhir telah menunjukkan bahwa dalam berbicara, kita sebenarnya melakukan hal-hal yang menakjubkan. Sistem pengetahuan yang bermacam-macam saling terkait saat manusia berbicara dan mengikuti kondisi waktu yang ketat kapan sebuah kata kita tuturkan. Kita mengambil sebuah kata dari gudang penyimpanan ingatan kita yang disebut leksikon mental sekitar dua hingga lima kali per detik. Manusia membuat keputusan kata mana yang hendak dituturkan dari basis data yang berjumlah sekitar 30.000-60.000 kata yang tersimpan dalam leksikon mental (Levelt 1989, dalam Marx 2000). Tingkat kesalahan yang dilakukan manusia dalam pemilihan kata sangat rendah; Levelt memperkirakannya pada 1:1000. Wijnen (dalam Vitevich et.al, 2015) memperkirakan bahwa orang dewasa dapat melakukan kesalahan ucapan atau kilir lidah setiap 1000 kata yang dihasilkan, sedangkan anak kecil dapat membuat 4 hingga 8 kesalahan ujaran per setiap 1000 kata yang dihasilkan. Ini berarti bahwa proses pengambilan leksikal dari leksikon mental dicirikan oleh kecepatan dan presisi yang ekstrim. Kemampuan berbicara terjadi dengan sangat otomatis dan biasanya tanpa kita sadari. Namun, ketika kita membuat kesalahan ujaran atau yang disebut dengan kilir lidah, kita dapat mengenali kembali jejak karakteristik kesalahan tersebut dan hal itu memberi kita petunjuk tentang 
bagaimana aktivasi dan penggunaan berbagai sumber pengetahuan terjadi saat kita berbicara. Jadi, dengan mengetahui bagaimana kilir dapat lidah terjadi, kita dapat mengetahui proses-proses apa saja yang dilalui manusia sebelum kegiatan berbicara berlangsung. Ketika meneliti kilir lidah, para ahli dari bidang bahasa, psikolinguistik dan psikologi di satu sisi tertarik pada klasifikasi fenomena kilir lidah dan, di sisi lain, terutama pada pertanyaan tentang bagaimana manifestasi yang sangat berbeda dari kilir lidah dapat dijelaskan penyebabnya. Selanjutnya, kilir lidah juga dibedakan dari kesalahan ujaran yang terjadi akibat gangguan berbahasa karena kerusakan otak sebagai akibat dari strok, trauma, tumor etc. Dalam kasus seperti itu biasanya terjadi gengguan berbahasa yang disebut afasia. Kilir lidah yang tidak direncanakan juga harus dibedakan dari kesalahan ucap yang disengaja untuk menimbulkan efek tertentu dalam berkomunikasi seperti misalnya pada kabaret, ironi, satire atau lelucon yang biasa 'memplesetkan' kata.

Penelitian ini merupakan kajian psikolinguistik dan bertujuan untuk meneliti jalannya proses kilir lidah yang terjadi pada penutur dewasa Bahasa Indonesia. Sementara ahli bahasa berurusan dengan aturan linguistik dan fitur struktural bahasa, misalnya dengan kekhasan sistem struktural pada bahasa yang mempunyai penanda jender, bidang psikolinguistik mengkaji proses berbicara dan pemahaman, yaitu penggunaan bahasa secara konkrit. Berkat kajian tentang kilir lidah, kita tahu bahwa kesalahan bicara tidak muncul secara acak, tetapi mengikuti keteraturan tertentu. Asumsi dasar dari penelitian kesalahan ujaran atau kilir lidah adalah bahwa keteraturan ini juga mendasari ucapan yang bebas gangguan. Kilir lidah merupakan "gangguan bicara normal", sebagai lawan dari gangguan bicara yang terjadi secara patologis (Pechmann,1994). Kilir lidah tidak menyangkut masalah kompetensi linguistik, tetapi performansi linguistik. Penutur menyadari bahwa dia telah salah ucap atau "terkilir lidahnya", sedangkan pada tataran kompetensi linguistik, penutur tidak menyadari kesalahan yang terjadi karena kurangnya kompetensi.

Sebagian besar kajian kilir lidah, baik berbasis korpus maupun eksperimental, dilakukan untuk mendukung studi tentang produksi ujaran. Kilir lidah dapat memberi tahu kita apa saja yang mungkin salah selama produksi ujaran, dan, yang sama pentingnya, hal-hal apa yang tidak pernah salah. Karena alasan ini, kilir lidah dianggap sebagai "jendela pikiran" (Fromkin dalam Poulisse, 1999: 8). Lebih jauh, kilir lidah juga diteliti dalam berbagai perspektif, misalnya kilir lidah dalam konteks wacana rasial (Burford-Rice \& Augoustinos, 2017; Goodman, S., \& Burke, S., 2011), kilir lidah pada anak-anak (Jaeger, 2005), kilir lidah dalam produksi bahasa pertama dan kedua (Poulisse,1999), kilir lidah dalam kajian jender (Altiparmak \& Kuruoğlu, 2018), kilir lidah dalam pembelajaran bahasa asing (Veličkova, 2007), kilir lidah dalam konteks neorologi (Strijkers \& Costa, 2015) dan lain-lain. Kajian kilir lidah juga sudah dilakukan di Indonesia terutama dengan pendekatan linguistik murni, namun karena kilir lidah sifatnya spontan dan dapat terjadi di berbagai kegiatan berbicara manusia, maka kajian ini tetap menarik untuk dikaji dari perspektif yang berbeda.

Penelitian ini berfokus pada bagaimana bentuk kilir lidah yang terjadi pada pembicaraan spontan penutur dewasa Bahasa Indonesia dan Latar belakang apa yang mendasari terjadinya kilir lidah tersebut.

\section{Metode}

Penelitian ini merupakan penelitian deskriptif kualitatif dengan data penelitian berupa produksi ujaran penutur Bahasa Indonesia. Data dikumpulkan selama kurang lebih enam bulan dengan metode simak dengan teknik simak bebas libat cakap (SBLC). Teknik pemeriksaan keabsahan data dilakukan melalui ketekunan peneliti, triangulasi, dan kecukupan referensi. Data untuk penelitian ini adalah 45 kilir lidah yang dikumpulkan sebagian besar dari percakapan spontan di antara penutur asli dewasa di Indonesia dan dari acara bincang-bincang di televisi, serta percakapan tanpa naskah di radio dan televisi. Data dianalisis berdasarkan kategori jenis kesalahan dan kemudian diberi keterangan latar belakang terjadinya kesalahan tersebut. Pengumpulan data dilakukan oleh dua peneliti dan dibantu mahasiswa selama enam bulan.

\section{Hasil dan Diskusi}

Bagian ini memuat klasifikasi kilir lidah dalam data kami berdasarkan jenis kesalahan yang diadaptasi dari Meringer (dalam Luger, 2006:34). Hasil penelitian ini akan menggambarkan pola kesalahan kilir lidah yang paling umum ditemukan di korpus Indonesia kami. Sedikitnya satu contoh diberikan untuk setiap satu kategori jenis kesalahan beserta pembahasannya. 


\section{Pertukaran}

Pertukaran biasanya terjadi pada bagian ucapan yang memunyai kelas kata yang sama. Pertukaran terjadi pada kata, bagian dari kata majemuk, suku kata, atau bahkan bunyi yang berubah tempatnya. Pertukaran tidak menyebabkan terjadi bentukan kata baru, namun terdapat pertukaran kata dengan kata yang mempunyai kemiripan bentuk. Contoh dari korpus kami:

(1). A : Kamu harusnya tidur dong, jangan bedagang terus, eh begadang!

(2) A: Makalahnya mau aku reparasi dulu ya. B: revisi neng cantik!

Pada contoh (1) terjadi pertukaran kata bedagang dengan begadang dalam kelas kata yang sama yaitu verba. Suku kata yang tertukar antara da gang dan ga dang. Kilir lidah ini terjadi karena tertukarnya suku kata pertama dari kata kedua dengan suku kata pertama dari kata yang hendak diucapkan.

Kilir lidah pada contoh (2) terjadi karena penutur menukar kata reparasi dengan revisi yang secara sekilas mempunyai makna sama dan dengan kelas kata yang sama pula namun kedua kata tersebut mempunyai konteks penggunaan yang berbeda. Saat kita mengakses sebuah kata, langkah pertama adalah menggunakan informasi konseptual untuk memilih lema yang fitur semantiknya memenuhi kondisi yang ditentukan dalam input konseptual. Dalam kondisi terburu-buru, kemungkinan kesalahan memilih lema yang sesuai bisa memicu terjadinya kilir lidah.

\section{Antisipasi}

Dalam kasus antisipasi, satuan unit linguistik diantisipasi dalam sebuah ujaran. Satuan ini dapat berupa satuan kebahasaan seperti pada kasus pertukaran yaitu kata, komponen kata, atau kelompok fonetik / bunyi. Dalam pemrosesan kebahasaan, leksikon mental digunakan sebagai penyimpan pengetahuan deklaratif tentang kata-kata. Pengetahuan umum penutur ditampilkan di luar pemrosesan kebahasaan. Pengetahuan tersebut tidak hanya berisi pengetahuan terstruktur tentang dirinya dan lingkungannya, tetapi juga informasi tentang situasi saat ini serta pengetahuan tentang lawan bicara, dll. Jika pengetahuan tersebut kurang, maka bisa memicu kilir lidah. Contoh dari korpus kami:

\section{(1). A: Apapun yang akan kamu lakukan, itu seterah kamu.}

Pada contoh ini terjadi kekeliruan suku kata pada kata terserah suku kata /terse/ bertukar dengan /setel jadi kata yang seharusnya diucapkan seharusnya terserah menjadi seterah. Kekeliruan ini terjadi karena penutur mengetahui bahwa dalam kata terserah terdapat suku kata ter dan se namun terjadi kekeliruan dalam posisi pengucapan. Para psikolog dan ahli bahasa juga mendalami tentang organisasi dan representasi struktur semantik. Proses perencanaan dalam pembuatan konsep sangat bergantung pada konteks.

\section{Posisi akhir (Postposisi)}

Postposisi (posisi akhir) atau pengulangan merupakan kebalikan dari antisipasi. Di sini unsur-unsur kebahasaan yang sudah digunakan atau diucapkan masih aktif dalam perencanaan bahasa di leksikon mental dan oleh karena itu digunakan secara tidak benar untuk kedua kalinya (substitusi atau penambahan). Kilir lidah pada jenis ini dapat terjadi pada kata, komponen kata, atau kelompok fonetik / bunyi. Contoh dari korpus kami:

(1). A: Kemudian ada laporan dari hasil pemeriksaan laboratorium polisi Porli yang menyatakan bahwa...

Pada kalimat tersebut terdapat transposisi atau pertukaran huruf $r$ dengan $l$, yaitu memindahkan kata atau bunyi dari suatu posisi ke posisi yang lain. Huruf ketiga seharusnya yaitu /l/, sedangkan huruf keempat yaitu /r/ maka kata tersebut menjadi /Polri/, bukan /Porli/. Kata polisi yang sudah disebutkan sebelum kata polri menjadi pemicu terjadinya kilir lidah jenis ini. Kesalahan frasa nominal ini terjadi karena dua kata benda diberikan prosedur kata benda pada saat yang bersamaaan (polisi dan polri) sehingga tertukar pada kata porli. 
Kontaminasi

Kontaminasi dianggap sebagai kilir lidah yang paling menarik karena dalam kontaminasi dua unsur kebahasaan dicampur menjadi satu sehingga membentuk unsur yang biasanya sama sekali baru. Masalah pemilihan kata menyangkut pertanyaan tentang informasi mana yang akan disebutkan dan informasi mana yang harus dikesampingkan. Masalah linierisasi penutur melibatkan pertanyaan tentang urutan di mana ia dapat menyampaikan informasi yang dipilih dengan baik agar kontaminasi dapat dihindari. Contoh dari korpus kami:

(1) A: Udara disini masih serah ya, eh maksud saya segar dan cerah.

Kata yang dimaksud penutur sebenarnya adalah segar dan cerah, namun penutur menghasilkan kata yang tidak terdapat dalam Bahasa Indonesia yaitu serah yang merupakan kontaminasi dari segar dan cerah.

\section{Substitusi}

Substitusi atau pergantian terjadi berdasarkan kemiripan makna atau bentuk. Saat mengganti kata yang mempunyai kemiripan bentuk, kilir lidah mengikuti aturan tertentu; Kata yang salah biasanya memiliki jumlah suku kata yang sama, akhiran dan bunyi awal yang sama atau paling tidak hampir dirasakan sama dengan kata yang seharusnya diucapkan. Contoh dari korpus kami:

(1). A : Coba kamu sekarang lafalkan bacaan ini, lalu tampilkan ke ibu ya?

B : lafalkan saja bu?

A : eh maksudnya hafalkan.

(2). A : Tolong ambilkan jilbab kakak yang warna hijau ya de.

B : Tidak ada warna hijau kak, adanya warna biru.

A : oh iya warna biru maksudnya.

Kekeliruan substitusi pada kalimat (1) terjadi karena adanya kemiripan akustik antara kata hafal dan lafal walaupun berbeda makna. Kedua kata tersebut mempunyai jumlah suku kata yang sama dan kelas kata yang sama. Dalam konteks kurang konsentrasi misalnya, dapat memicu terjadinya kilir lidah.

Contoh pada kalimat (2) merupakan seleksi makna kata warna yang keliru. Si penutur mengingat kembali kata dan mengambilnya dari leksikon mental namun ternyata bukan kata yang ia perlukan. Hal ini dikarenakan kita menyimpan kata berdasarkan sifat-sifat yang ada pada kata-kata itu. Kekeliruan pada seleksi semantik ini pada umumnya berwujud kata yang utuh dan berasal dari medan makna yang sama. Dalam proses perumusan kata, struktur konseptual diterjemahkan ke dalam struktur linguistik. Sub-proses utama adalah pemilihan leksikal dan pembuatan struktur sintaksis. Akibatnya, proses pengkodean tata bahasa menghasilkan organisasi hierarki dari frasa sintaksis. Simpul akhir dari pohon frase ini adalah lema, yaitu elemen leksikal yang telah ditentukan secara semantik dan sintaksis, tetapi belum secara fonologis.

Tabel 1. Kilir Lidah pada Penutur Dewasa Bahasa Indonesia

\begin{tabular}{|c|c|c|c|}
\hline No. & Jenis kilir Lidah & Contoh & Keterangan \\
\hline 1. & Pertukaran & $\begin{array}{l}\text { Bedagang= } \\
\text { Begadang }\end{array}$ & Pertukaran da $=$ ga \\
\hline 2. & Antisipasi & Seterah $=$ terserah & Kata ter diantisipasi lebih awal \\
\hline 3. & Posisi akhir & Porli $=$ polri & Posisi huruf 1 dan $r$ keliru setelah pengucapan kata polisi \\
\hline 4. & Kontaminasi & Serah $=$ segar cerah & Kontaminasi pada kata segar dan cerah \\
\hline 5. & Substitusi & lafal= hafal & Substitusi kata yang mirip secara bentuk dan makna \\
\hline & & hijau=biru & \\
\hline
\end{tabular}

Hasil penelitian ini sesuai dengan pernyataan Levelt (1989) dalam Marx (2000) yang mengupas tentang proses berbahasa mulai dari niat penutur dalam bentuk konsep sampai berbentuk ujaran. Menurut 
Levelt, proses ujaran dimulai dengan pemrosesan di bagian konseptualisasi ("menghasilkan pesan"). Bagian ini kemudian meneruskan hasilnya ke bagian perumusan yang mengubah representasi pralinguistik menjadi representasi linguistik. Hasil dari proses ini dapat diakses secara sadar dalam bentuk ucapan batin dan dapat dikendalikan oleh pembicara melalui sistem pemahamannya sendiri sebelum rancangan fonetik diteruskan ke alat artikulator. Monitor melakukan proses perbandingan dalam pembuatan konsep dengan maksud penutur yang mendasarinya ("pemantauan"). Pernyataan yang diartikulasikan juga dapat diperiksa dengan cara ini. Dalam pemrosesan kebahasaan, leksikon mental digunakan sebagai penyimpan pengetahuan deklaratif tentang kata-kata. Kilir lidah menurut pendekatan psikolinguistik dapat terjadi jika terdapat gangguan dalam proses berbahasa yang masih disadari penuturnya karena hanya bersifat performansi bukan kompetensi.

\section{Simpulan}

Dari penelitian diatas dapat disimpulkan bahwa terdapat lima jenis kilir lidah yang terjadi pada penutur Bahasa Indonesia sebagai bahasa ibu yaitu pertukaran, antisipasi, postposisi, kontaminasi, dan substitusi. Kilir lidah yang paling sering terjadi adalah pertukaran. Penelitian kilir lidah dapat memberi masukan terhadap proses berbahasa yang sangat penting bagi pengajaran bahasa. Pengajar bahasa dapat berinteraksi dengan pelajar lebih baik jika masalah yang menjadi sumber-sumber kesalahan pelajar dapat diketahui. Dengan menganalisis kesalahan berbahasa secara psikolinguistik, khususnya pada kilir lidah, dapat dibedakan hal-hal yang menjadi penyebab secara sengaja dan yang tidak disengaja, sehingga dapat diberikan upaya tindak lanjut dalam mengatasi masalah. Penelitian selanjutnya dapat berupa penelitian yang melibatkan lebih banyak data analisis agar dapat mencakup lebih banyak masukan tentang proses terjadinya kesalahan berbahasa pada umumnya.

\section{Ucapan Terima Kasih}

Penulis berterima kasih kepada mitra bestari jurnal Hortatori atas bantuan dalam penerbitan penelitian ini dan kepada rekan-rekan sejawat Unindra atas bantuan penyempurnaan pengumpulan data.

\section{Daftar Rujukan}

Altıparmak, Ayşe and Kuruoğlu, Gülmira. "Gender and Speech Disfluency Production: A Psycholıngustıc Analysıs on Turkısh Speakers". Psycholinguistics, 24 (2), 114-143. doi: 10.31470/2309-1797-2018-24-1-114-143. (2018): n. pag. Web. 4 April 2020.

Burford-Rice, Rose and Augoustinos, Martha. "I didn't mean that: It was just a slip of the tongue": Racial slips and gaffes in the public arena. British Journal of Social Psychology. The British Psychological Society. DOI:10.1111/bjso.12211. (2017): n. pag. Web. 3 April 2020.

Dimen, Muriel. "Lapsus Linguae, or A Slip of the Tongue?", Contemporary Psychoanalysis, 47:1, 35-79. DOI:10.1080/00107530.2011.10746441. (2011): n. pag. Web. 20 Juli 2020.

Forrester, Gillian and Rodriguez, Alina. "Slip of the tongue: Implications for evolution and language development". http://dx.doi.org/10.1016/j.cognitio n. (2015): n. pag. Web. 20 Agustud 2020.

Goodman, S., \& Burke, S. "Discursive deracialization in talk about asylum seeking". Journal of Community \& Applied Social Psychology,21, 111-123. https://doi.org/10.1002/casp.1065 (2011): n. pag. Web.

Gilquin, Gaëtanelle \& De Cock, Sylvie (Ed.). Errors and Disfluencies in Spoken Corpora. Amsterdam: John Benjamins Publishing Company, 2013. Print.

Jaeger, Jeri. Kids'slips. What Young Children's Slips of the Tongue Reveal About Language Development. New Jersey: Lawrence Erlbaum Associates, 2005. Print.

Luger, Veronika. Versprecher. Saarbrücken: VDM Verlag Dr. Müller, 2006. Print.

Marx, Edeltrud. Versprecher und Genusverarbeitung: Analysen spontaner und experimentell erzeugter Sprechfehler. Wiesbaden: Deutsche Universitätsverlag, 2000. Print.

Pechmann, T. Sprachproduktion. Zur Generierung komplexer Nominalphrasen. Opladen: Westdeutscher Verlag, 1994. Print.

Poulisse, Nanda. Slips of the Tongue. Speech Errors in First and Second Language Production. Amsterdam: John Benjamins, 1999. Print. 
Kristof Strijkers \& Albert Costa. "On Words and Brains: Linking Psycholinguistics with Neural Dynamics in Speech Production". Language, Cognition and Neuroscience, DOI: 10.1080/23273798.2016.1158845. (2016): n. pag. Web. 13 Juli 2020.

Veličkova, Ludmila, Phonologische und psycholinguistische Probleme des Ausspracheunterrichts. Zeitschrift für Interkulturellen Fremdsprachenunterricht 12:2, 2007, 17 S.. Print.

Vitevitch MS, Siew CSQ, Castro N, Goldstein R, Gharst JA, Kumar JJ and Boos EB (2015) Speech error and tip of the tongue diary for mobile devices. Frontiers Psychology. 6:1190. doi: 10.3389/fpsyg.2015.01190. (2015): n. pag. Web. 23. Juli 2020. 